\title{
Checklist of tidepool fishes from Jericoacoara National Park, southwestern Atlantic, with additional ecological information
}

\author{
Fabiola S. Machado ${ }^{1,2,3}$, Raphael M. Macieira ${ }^{1,2}$, Mario A. Zuluaga Gómez ${ }^{1,2}$, Alexandra F. Costa ${ }^{1,2}$, \\ Esther M.C. Mesquita ${ }^{1,2}$ \& Tommaso Giarrizzo ${ }^{1,2}$ \\ ${ }^{1}$ Programa de Pós-graduação em Ecologia Aquática e Pesca, Instituto de Ciências Biológicas, Universidade \\ Federal do Pará. Av. Augusto Corrêa, No 1, Guamá. CEP 66075-110, Belém, PA, Brazil. \\ ${ }^{2}$ Laboratório de Biologia Pesqueira e Manejo dos Recursos Aquáticos, Instituto de Ciências Biológicas, \\ Universidade Federal do Pará. Av. Perimetral, 2651, Terra Firme. CEP 66077-570, Belém, PA, Brazil. \\ ${ }^{3}$ Corresponding author: Fabiola S. Machado, e-mail: fabiola_seabra@hotmail.com
}

MACHADO, F.S., MACIEIRA, R.M., ZULUAGA GÓMEZ, M.A., COSTA, A.F., MESQUITA, E.M.C., GIARRIZZO T. Checklist of tidepool fishes from Jericoacoara National Park, southwestern Atlantic, with additional ecological information. Biota Neotropica. 15(1): e20140111. http://dx.doi.org/10. 1590/1676-06032015011114

\begin{abstract}
Ichthyofauna from 29 tidepools in Jericoacoara National Park (Ceará State, Brazil) was sampled. A total of 733 fishes, comprising 16 species belonging to 12 families, was collected. The three most abundant species were the frillfin goby Bathygobius soporator, the sergeant-major Abudefduf saxatilis and the molly miller Scartella cristata. An invasive species from the Indo-Pacific, the Muzzled blenny Omobranchus punctatus, was also recorded. The known geographic distribution of the blenny Hypleurochilus fissicornis was extended approximately $2,500 \mathrm{~km}$ northward. These findings highlight the lack of knowledge of the rocky intertidal ecosystems along the Brazilian coast, an area that needs more sampling effort and ecological data.
\end{abstract}

Keywords: rockpools, reef, intertidal zone, fish community, rocky shore.

MACHADO, F.S., MACIEIRA, R.M., ZULUAGA GÓMEZ, M.A., COSTA, A.F., MESQUITA, E.M.C., GIARRIZZO T. Inventário dos peixes de poças de mare do Parque Nacional de Jericoacoara, Atlântico sudoeste, com informações ecológicas adicionais. Biota Neotropica. 15(1): e20140111.http://dx.doi. org/10.1590/1676-06032015011114

Resumo: Um total de 733 espécimes de peixes, pertencentes a 16 espécies (12 famílias), foi capturado em 29 poças de maré no Parque Nacional de Jericoacoara (Ceará, Brasil). As espécies mais numericamente abundantes foram o amboré Bathygobius soporator, o sargentinho Abudefduf saxatilis e o macaco-verde Scartella cristata. Uma espécie invasora originária do Indo-Pacífico, Omobranchus punctatus, foi registrada para a área. A ocorrência de Hypleurochilus fissicornis permitiu expandir sua distribuição geográfica em cerca de $2.500 \mathrm{~km}$ ao norte. Esses resultados demostram que diversos aspectos relacionados a ictiofauna do ecossistema entremarés em substrato consolidado ainda permanecem pouco estudados no Brasil, e portanto, mais levantamentos da biodiversidade e dados ecológicos são necessários.

Keywords: recife, zona de entremaré, costão rochoso, espécie invasora.

\section{Introduction}

Historically, intertidal ecosystems have been explored by humans (Horn et al. 1999, Mobley \& McCallum 2001, Mannino \& Thomas 2002, Thompson et al. 2002, Steele \& Klein 2008), and remain an important provider of resources. Seafood, honey, traditional medicine, tannins, timber and firewood are some of the intertidal ecosystem goods used by humans (Addessi 1994, Moberg \& Rönnbäck 2003, Fletcher et al. 2012). However, the biodiversity and ecological processes of some intertidal ecosystems, such as tidepools, remain understudied in many countries (Norton \& Cook 1999, Prochazka et al. 1999), despite the long history of exploitation of these systems. For example, approximately six references (i.e., Rosa et al. 1997, Barreiros et al. 2004, Macieira \& Joyeux 2009, 2011, Nunes et al. 2011, Macieira et al. 2014; excluding thesis, gray literature and works using visual census sampling methods) investigated the ecological aspects of Brazilian tidepool fishes. Although, fishes are an important component of many aquatic ecosystem (Holmlund \& Hammer 1999) and one of the most exploited live marine resources (King 2007). The historical increase of the coastal human population, and its economic activities (e.g., ports, industry, fishery, exploitation of oil and gas), pose a threat the intertidal ecosystem. The increase and diversification of anthropogenic impacts (e.g., eutrophication, habitat loss, introduced species, oil spills, pollution), have 
resulted in a loss of biodiversity and its functions and, consequently, a reduction or interruption of the ecosystems' services (Thompson et al. 2002, Moberg \& Rönnbäck 2003, Halpern et al. 2008, Cardinale et al. 2012). Thus, assessing the biodiversity and understanding the ecological processes of coastal ecosystems through the monitoring of marine communities, where basic information (e.g., the list of species) are lacking is essential to ensure the systems' health. This study presents the first checklist for the tidepool fishes from Jericoacoara National Park. In addition, estimations of body size, density and biomass are provided, and the patterns of species geographic distribution and one range extension are discussed.

\section{Materials and Methods}

\section{Study Area}

The Jericoacoara National Park is located in Ceará State in northeastern Brazil $\left(2^{\circ} 47^{\prime} \mathrm{S}, 40^{\circ} 30^{\prime} \mathrm{W}\right)$, with an area of 8,416 ha composed of a mosaic of landscapes (i.e., cliffs, mangroves, sandy beaches, sandy dunes and rocky intertidal shore; Figure 1). In the northern part, the intertidal zone is dominated by a beachrock formation, and diversified sessile fauna and flora (i.e., ascidians, corals, macroalgae and sponges) partially cover the rocky shore and the tidepools (Figure 2). The regional climate is tropical semi-arid (mean: $27^{\circ} \mathrm{C}$ temperature, $989 \mathrm{~mm}$ rainfall); during the dry season the trade winds are more intense (reaching $15 \mathrm{~m} / \mathrm{s}$ ). The coastal circulation is driven by the North Brazil current and by semidiurnal mesotides (Meireles 2011, MMA 2011).

\section{Data collection}

Samples were collected with the permission of the Instituto Chico Mendes de Conservação da Biodiversidade (ICMBio) and Sistema de Autorização e Informação em Biodiversidade (SISBIO), license number 35625. Sampling was conducted during daytime, at low tide of the spring tide, in September 2012. Twenty-nine tidepools (without connectivity to the sea or other pools during the ebb tide) were randomly sampled in a surveyed area of $3.32 \mathrm{~km}^{2}$ (Figure 1). The physicochemical parameters of water and morphological characteristics were measured in each pool. Temperature, $\mathrm{pH}$ and salinity were measured with a mercury thermometer $\left( \pm 0.1^{\circ} \mathrm{C}\right.$ precision), a ClolorpHast tape $( \pm 1)$ and an optical refractometer (Model: Q767; \pm 0.1$)$, respectively. Rugosity was measured by the chainand-tape technique (Wilding et al. 2010) and was replicated three times per pool to obtain a mean value. The topography and bathymetry of the rockpool were surveyed using a $20 \mathrm{~cm} \times$ $20 \mathrm{~cm}$ grid for the measurement of its depth within each square. With this information, the area and volume of each pool were calculated by kriging the data points in ArcGIS software. The substrate composition of each tidepool was estimated following Cox (2007), and categorized as sand (grain size $<1 \mathrm{~mm}$ ), gravel $(\leq 50 \mathrm{~mm})$ and rock $(>50 \mathrm{~mm})$. The sum of all categories corresponded to $100 \%$ of the substrate composition. The ichthyofauna was sampled using hand nets, and application of an alcohol clove-oil solution to the pool's water (Griffiths 2000, Ackerman \& Bellwood 2002, Cunha \& Rosa 2006). The specimens were fixed in $10 \%$ formalin, preserved in $70 \%$ alcohol, and subsequently, measured total length (TL) and total weight (WT) with a precision of $0.1 \mathrm{~mm}$ and $0.01 \mathrm{~g}$, respectively. Density and biomass were expressed as the number of individuals and weight $(\mathrm{g})$ per volume of pool $\left(\mathrm{m}^{3}\right)$, respectively. Voucher specimens were deposited in the fish collection at the ichthyological collection of the Grupo de Ecologia Aquática (GEA.ICT), and the numbers are given in the appendix. The species were categorized by their degree of residency in pool habitats as permanent residents, opportunists, and transients following Macieira \& Joyeux (2011). Zoogeographical affinities of the tidepool fishes in Jericoacoara National Park were analyzed, and the species were categorized by their geographic distribution (modified from Luiz Jr. et al. 2008) into the following categories: $\mathrm{CA}=$ Central Atlantic (St. Paul's Rocks, Ascension and St. Helena); SW = Southwestern Atlantic (Argentinian and Brazilian province-sensu Briggs \& Bowen 2012); TA = Trans-Atlantic (both sides of the Atlantic Ocean); and WA $=$ Western Atlantic (in the western north and south
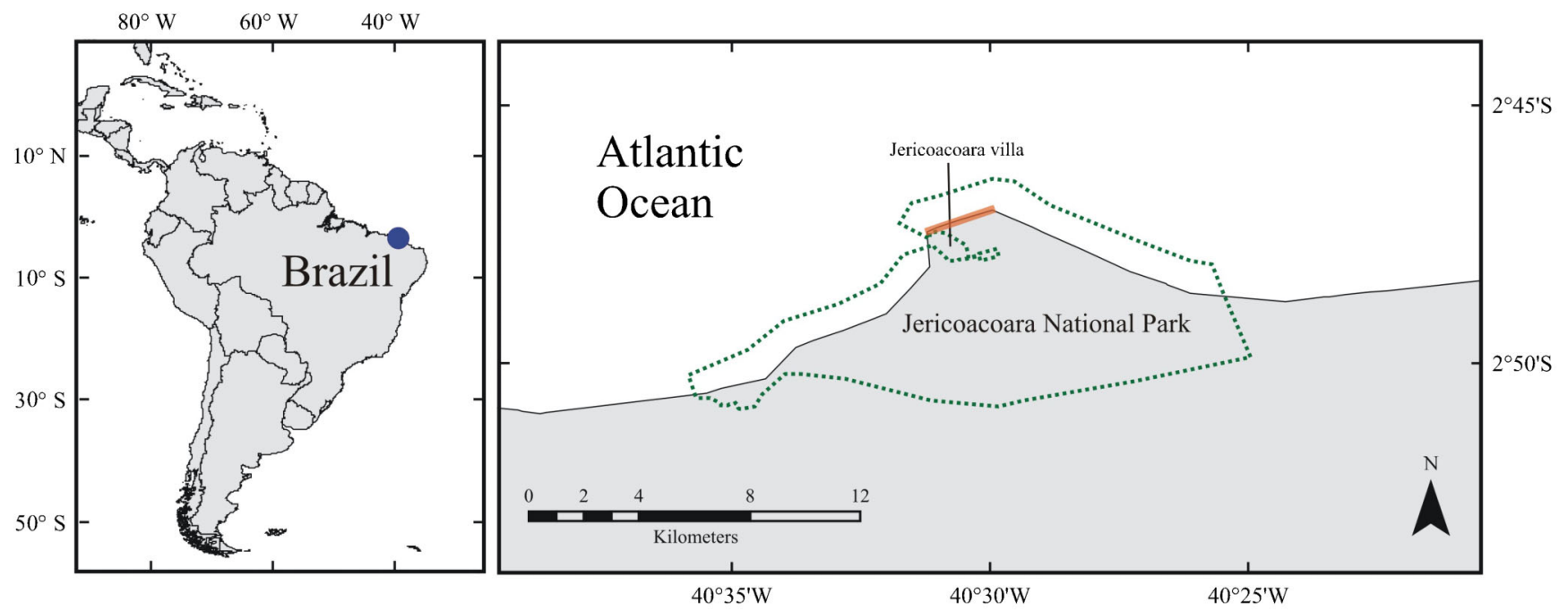

Figure 1. Geographic position of Jericoacoara National Park (blue circle) in the southwestern Atlantic. Delineation of the protected area on the Brazilian coast (dotted green line), and the area sampled (orange area). 

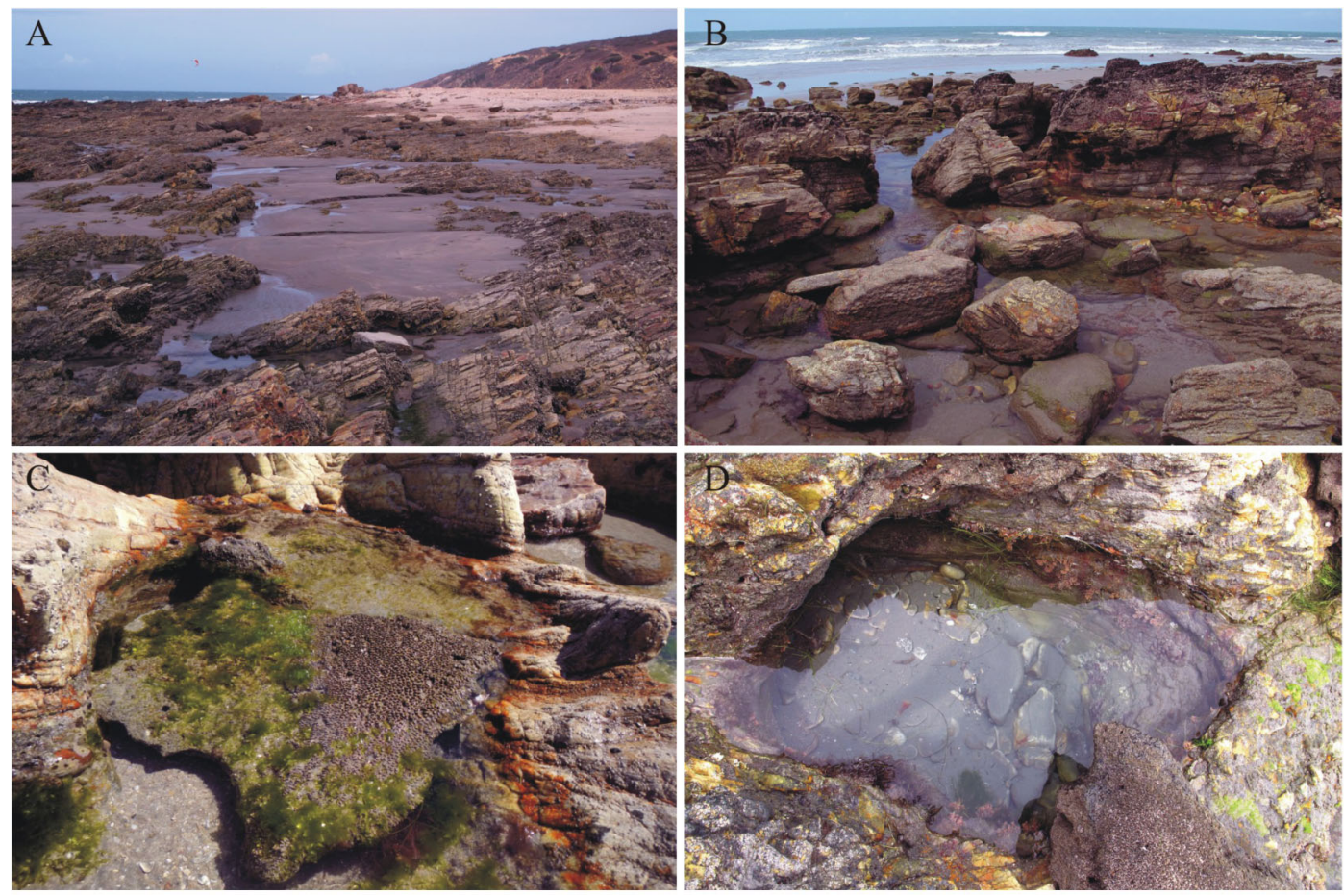

Figure 2. Landscapes of the rocky intertidal zone at ebb tide at Jericoacoara National Park, Brazil. (A-B) Beachrock formation at intertidal zone; (C-D) Details of the rockpools. Photos: Tommaso Giarrizzo.

Atlantic). A single species Omobranchus punctatus (Valenciennes 1836) was not evaluated for geographic distribution because it is classified as an exotic species.

\section{Results}

The rockpools were similar in physicochemical parameters of water but quite different in their morphological characteristics (Table 1). Temperature was the most variable physicochemical parameter, and the $\mathrm{pH}$ differences were minor.

A total of 733 individuals, comprising 16 species belonging to 12 families, was captured at Jericoacoara National Park (Table 2 and Figure 3). The mean ( \pm SD) density and biomass were $143.96 \pm 203.86$ ind $\mathrm{m}^{-3}$ and $24.61 \pm 31.16 \mathrm{~g} \mathrm{~m}^{-3}$, respectively, and the mean size (TL) was $53.2 \pm 2.82 \mathrm{~mm}$ (range $8.0-451.0 \mathrm{~mm}$ ). Except for the green moray Gymnothorax funebris Ranzani 1839, the community was composed of small species or juveniles of medium-sized species. The family Blenniidae was the most specious (three species) in this site, with the others composed of only one or two species. The frillfin goby Bathygobius soporator (Valenciennes 1837) $(\mathrm{n}=$ 183), molly miller Scartella cristata (Linnaeus 1758) (173), sergeant-major Abudefduf saxatilis (Linnaeus 1758) (122), twinspotted frillfin Bathygobius geminatus Tornabene, Baldwin \& Pezold 2010 (73) and blenny Malacoctenus delalandei (Valenciennes 1836) (72) were the most representative species ( $85 \%$ of the total caught). These same five species showed highest density, but biomass $\left(\mathrm{g} \mathrm{m}^{-3}\right)$ was more expressive for $S$. cristata (mean \pm standard deviation $143.1 \pm 422.7$ ), B. soporator (120.9 \pm 187.7$)$, A. saxatilis $(51.52 \pm 116.3)$, dog snapper Lutjanus jocu (Bloch \& Schneider 1801) (47.81 \pm 236.95) and G. funebris $(20.75 \pm 82.19)$. Among these, only $A$.

Table 1. Mean \pm standard deviation $(\mathrm{N}=29)$, minimum and maximum values of the environmental parameters of tidepools at Jericoacoara National Park, Ceará State, Brazil.

\begin{tabular}{lccc}
\hline Environmental parameters & Mean \pm standard deviation & Minimum & Maximum \\
\hline Physicochemical parameters & & & \\
pH & $8.6 \pm 0.1$ & 8.5 & 9.0 \\
Salinity & $35.6 \pm 0.6$ & 35.0 & 37.0 \\
Temperature $\left({ }^{\circ} \mathrm{C}\right)$ & $27.8 \pm 1.7$ & 24.5 & 30.5 \\
Morphological characteristics & & & \\
Area $\left(\mathrm{m}^{2}\right)$ & $4.8 \pm 4.3$ & 0.50 & 20.1 \\
Sand Coverage $(\%)$ & $44.6 \pm 27.7$ & 0.0 & 100.0 \\
Rock Coverage $(\%)$ & $40.6 \pm 24.8$ & 0.0 & 83.0 \\
Gravel Coverage $(\%)$ & $24.8 \pm 24.9$ & 0.0 & 100.0 \\
Rugosity & $1.6 \pm 0.5$ & 1.1 & 3.3 \\
Volume $\left(\mathrm{m}^{3}\right)$ & $0.3 \pm 0.2$ & 0.01 & 1.30 \\
\hline
\end{tabular}




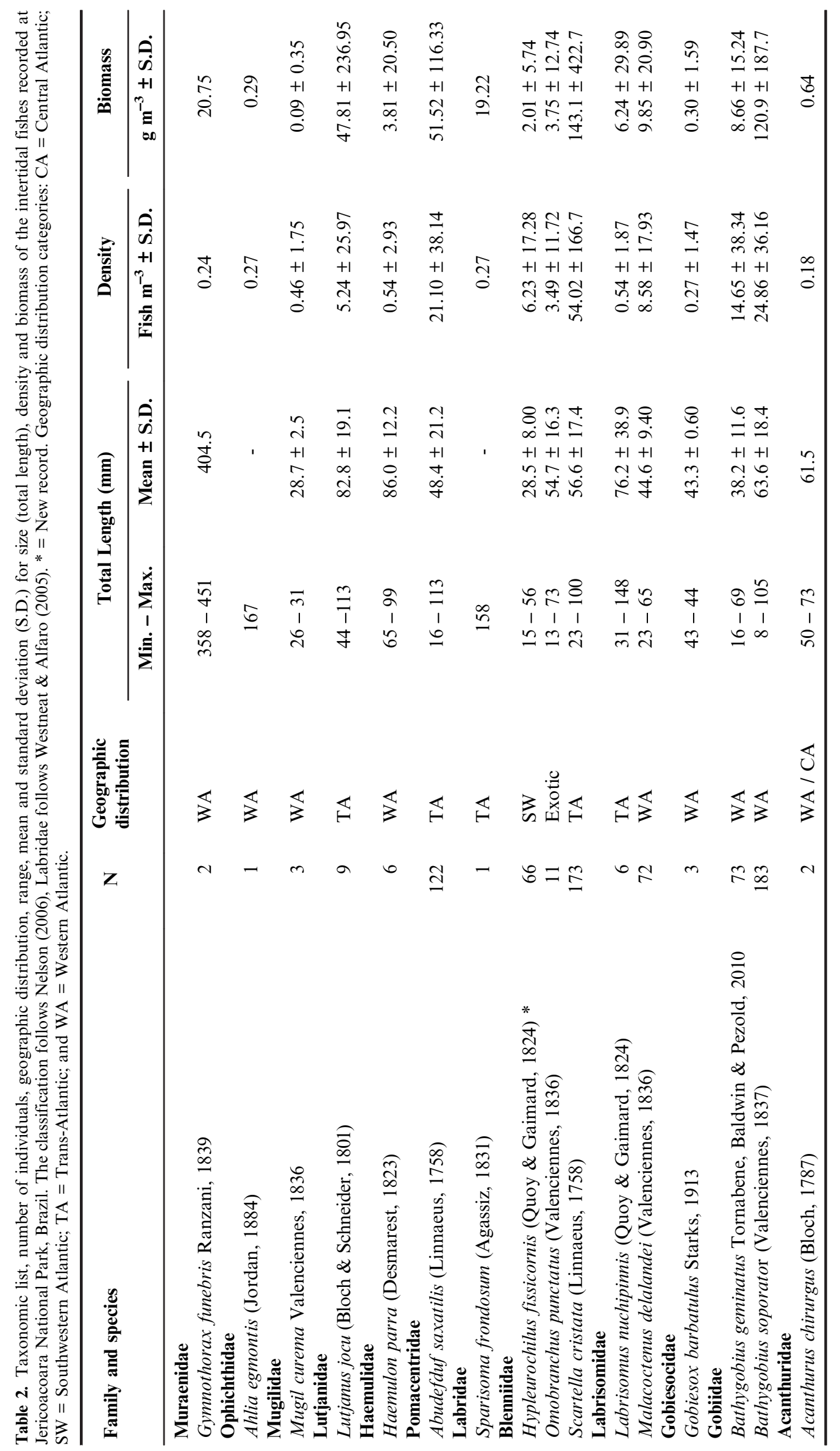



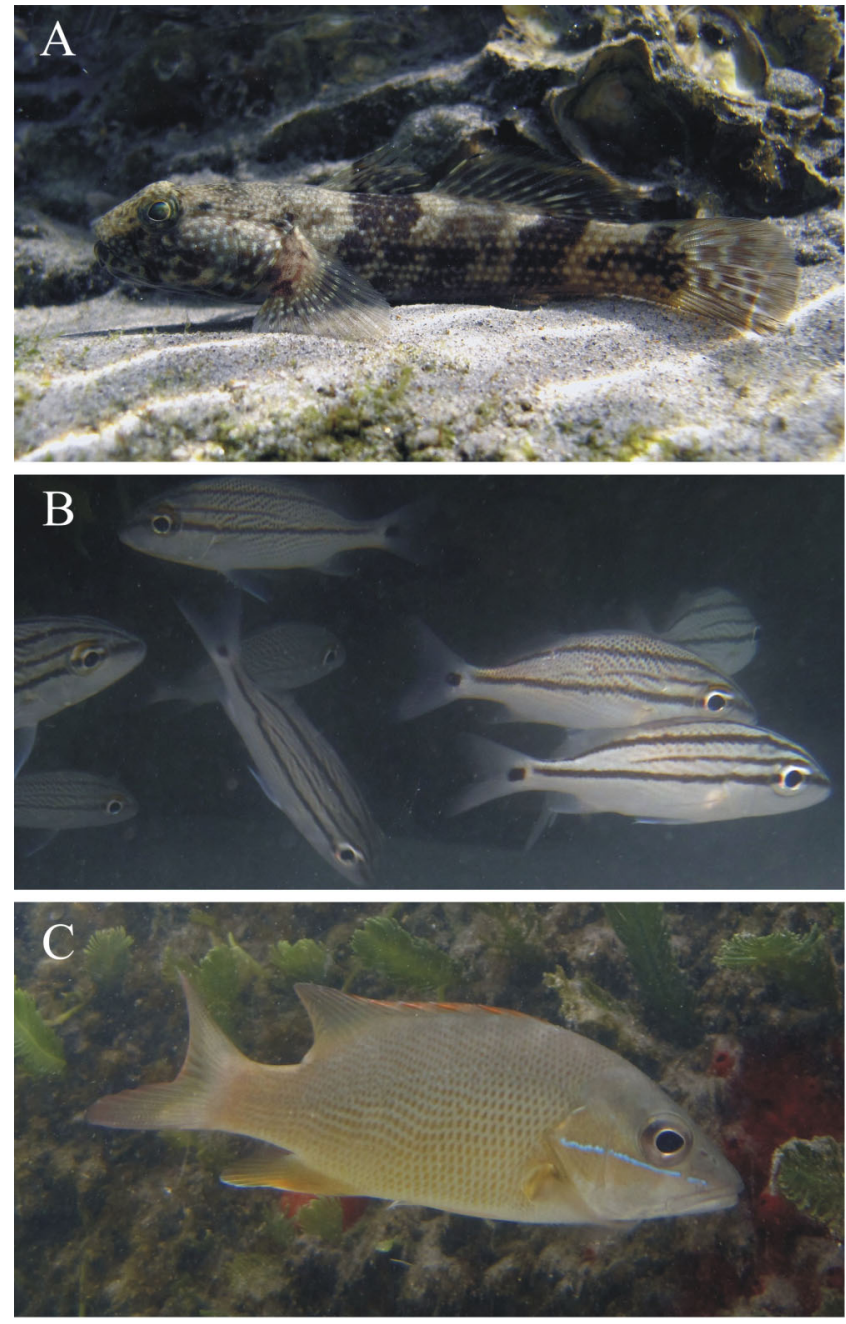

Figure 3. Some fish species of the rockpools at Jericoacoara National Park, Brazil. (A) Bathygobius soporator, (B) school of Haemulon parra, (C) Lutjanus jocu. Photos: Tommaso Giarrizzo.

saxatilis and $L$. jocu were not considered permanent resident of rockpools. The occurrence of the muzzled blenny Omobranchus punctatus is reported for the first time in the state of Ceará (Jericoacoara National Park), where 11 specimens were collected in this survey, with a mean density of 3.49 ( \pm 11.72$)$ ind. $\mathrm{m}^{-3}$ and a biomass $3.75 \mathrm{~g} \mathrm{~m}^{-3}( \pm 12.74)$. The occurrence of the blenny Hypleurochilus fissicornis (Quoy \& Gaimard 1824) at Jericoacoara National Park extends the known distribution of this species by approximately $2,500 \mathrm{~km}$ northward. The previously known geographic distribution of this species was $20^{\circ} \mathrm{S}$ (Brazil) to $40^{\circ} \mathrm{S}$ (Argentina) and covered approximately $3,000 \mathrm{~km}$ (Menezes \& Figueiredo 1985, Irigoyen \& Galván 2009, Rangel \& Guimarães 2010). A total of 66 H. fissicornis were captured with a mean density and biomass of $6.23( \pm 17.28)$ ind. $\mathrm{m}^{-3}$ and $2.01( \pm 5.74) \mathrm{g} \mathrm{m}^{-3}$, respectively.

The geographic distribution of the tidepool fishes from Jericoacoara National Park demonstrates that half of all species (8) were distributed exclusively in the western Atlantic, five occurred on both sides of the Atlantic Ocean, and the other four species had distinct distribution ranges. However, only the molly miller $S$. cristata had a wide distribution in the Atlantic Ocean and the Mediterranean Sea.

\section{Discussion}

The homogeneity in physicochemical parameters of water between tidepools, indicates a similar physiological stress condition for the tidepool communities. A strong variability was detected in the morphological characteristics that could indicate an ecosystem with many types of microhabitats, and may denote a diversified spectrum of niches (Mouillot et al. 2007, Macieira \& Joyeux 2011). These features seem to be associated to flat reefs (e.g., Macieira \& Joyeux 2011) or rocky shores, with discrete difference in height between pools, in areas where the intertidal zone daily inundated by the sea.

The composition of the tidepool fish community in Jericoacoara National Park is similar to other areas in Brazil, but the richness is lower than expected compared with sites in northeastern Brazil (e.g., Cabo Branco, Paraiba state with 40 species, Rosa et al. 1997). Given that our sampling effort was concentrated in a unique sampling event, the present species list provides relevant information exclusively for permanent resident fish (e.g., 10 resident fish species in our study vs. 13 resident fish species in Cabo Branco, Rosa et al. 1997, in two pools sampled 24 times). Only with high temporal resolution sampling designs (e.g., monthly samples), could be achieved the record of opportunistic and transient fishes. Furthermore, difference in the number of species could be explained by several environmental factors such as structural complexity (Davis 2000, Griffiths et al. 2006, Rojas \& Ojeda 2010), morphology of pools (Mahon \& Mahon 1994, Macieira \& Joyeux 2011), substrate cover (Bennett \& Griffith 1984, Davis 2000, Arakaki \& Tokeshi 2011), vertical position (Gibson 1972 , Barton 1982, Davis 2000, Castellanos-Galindo et al. 2005, Cox et al. 2010) and exposure to waves (Gibson 1972, Grossman 1982). For example, the tidepools in Cabo Branco (see Rosa et al. 1997) are about 80-266 times voluminous than the sampled pools in Jericoacoara. According to Mahon \& Mahon (1994), there is a positive correlation between the abundance / richness of species and volume of pool. Furthermore, the non-resident fish commonly use these large pools (Mahon \& Mahon 1994, Macieira \& Joyeux 2011), which are absent in the intertidal zone of Jericoacoara National Park. The synergetic interaction of these factors modulates the intertidal fish community since they act as a species filter (Macieira \& Joyeux 2011), and the many combinations of factors result in different types of communities. Thus, only with standardized sampling design with high spatio-temporal resolution and similar quantitative methodologies could be possible to understand how the local and regional ecological drivers influence the fish assemblages in tidepool ecosystems.

The classic permanent resident fish families in tidepools, Blenniidae and Gobiidae (Prochazka et al. 1999), were expressive in terms of the number of species $(31.25 \%$ of all species) and dominant in abundance (69.03\% of all caught), density ( $73.25 \%$ of the total mean density) and biomass $(65.48 \%$ of the total mean biomass). The success of these families in occupying the intertidal ecosystem is related to morphological, physiological and behavioral specialized adaptations to intertidal life (Gibson 1986, Evans et al. 1999, Gibson 1999, Horn et al. 1999, Martin \& Bridges 1999). These adaptations allow occupancy an ample spectrum of niches and improve the capacity to compete for resources (e.g., food, shelter and nest site). Alternatively, the opportunists and transient species (i.e., generally without adaptation to intertidal life) are segregated to 
a specific type of pool (usually with large volume) with less stressful physiological conditions, but with an increase in the risk of predation and in the number of competitors (Mahon \& Mahon 1994, Macieira \& Joyeux 2011). The presence of juveniles of non-resident species could indicate the use of the tidepools as a nursery site and highlights the importance of this ecosystem to marine fishes (Gibson \& Yoshiyama 1999, Hernández et al. 2002, Krück et al. 2009). Future studies are needed to evaluate the dependence on pools by non-resident species, mainly those that are fishery-targeted species [e.g., $L$. jocu, Mugil curema Valenciennes 1836 and Sparisoma frondosum (Agassiz 1831)].

The analysis of the geographic distribution demonstrated an absence of endemic species, and the fishes were widely distributed. There are approximately 7 endemic species along the Brazilian coast (excluding oceanic islands; R.M. Macieira personal communication), but the absence of these endemic species in the Jericoacoara pools could be due to the sampling effort, because some species are rare and thus require a greater effort to capture (e.g., Letharchus aliculatus McCosker 1974; R.M. Macieira personal communication). Most of these species have high microhabitat specificity and the morphological structure of tidepools in Jericoacoara National Park may not be adequate.

Biological invasions are an actual and growing threat to ecosystems health (Pimentel 2011), and understanding the process, implications and consequences of invasions is key to minimizing their effects. The exotic species $O$. punctatus is native to the Indo-Pacific (Springer \& Gomon 1975) but is widely dispersed along the Brazilian coast in stabilized populations (e.g., Bahia, Maranhão, Pará, Piauí, Rio de Janeiro and Santa Catarina) (Gerhardinger et al. 2006, Lasso-Alcalá et al. 2011). However, biological (e.g., fecundity, growth) and ecological (e.g., niche, food habits) data about this invasion are still lacking. At Jericoacoara National Park, the presence of this exotic species during its entire life (i.e., juveniles to adults were caught sensu Froese \& Pauly 2014 - Life-history tool) and some characteristics such as small size, negative buoyancy, compressed body form, thigmotaxy, saltated swimming and cryptic behavior (Gibson 1986), permits it to be classified as a permanent resident. In addition, the density and biomass were comparable to others species (e.g., H. fissicornis and M. delalandei). Thus, O. punctatus has good potential to compete for resources with native species, especially the permanent resident species that use specific and limited resources as nest sites and shelter / rest areas. The effects of introduction cannot be completely evaluated because preterit data are absent, but simulations and ecological models could provide an interesting perspective of the invasion process.

In conclusion, the present work provides the first list of tidepool fishes from Jericoacoara National Park. Despite the lack of occurrence of endemic species and limited representatively of opportunistic and transient fishes, this work illustrates how a small concentrated effort can help fill the lack of knowledge and provide useful information to implement the management plan for this protected area. To promote the native biodiversity and maintain the presence of current species, we recommend (1) additional study in the area to determine the effects of the exotic species $O$. punctatus on native species, (2) long-term ecological research to monitor the ecosystem health (considering the low coast of sampling tidepool fishes and the importance of this component to system), and (3) modeling the effects of anthropogenic impacts on the food web by the modification of functional diversity.

\section{Acknowledgments}

This research was financially supported by the postgraduate program in Aquatic Ecology and Fishery (UFPA). We thank Wagner Cardoso and ICMBio Team for their cooperation and assistance during the field. FMS, MAZG, AFC, EMCM were funded by CAPES, and TG receives a productivity grant from CNPq (process: 308278/2012-7). RM and TG were funded by PNPD grant from CAPES. The authors belong to the $\mathrm{CNPq}$ Research Group: Grupo de Estudo de Peixes do Entremarés GEPE. The authors wish to thank the editor and anonymous reviewers for comments on an earlier version of this paper.

\section{References}

ACKERMAN, J.L. \& BELLWOOD, D.R. 2002. Comparative efficiency of clove oil and rotenone for sampling tropical reef fish assemblages. J. Fish. Biol. 60(4):893-901.

ADDESSI, L. 1994. Human disturbance and long-term changes on a rocky intertidal community. Ecol. Appl. 4(4):786-797.

ARAKAKI, S. \& TOKESHI, M. 2011. Analysis of spatial niche structure in coexisting tidepool fishes: null models based on multiscale experiments. J. Anim. Ecol. 80(1):137-147.

BARREIROS, J.P., BERTONCINI, Á., MACHADO, L., HOSTIMSILVA, M. \& SANTOS, R.S. 2004. Diversity and seasonal changes in the ichthyofauna of rocky tidal pools from Praia Vermelha and São Roque, Santa Catarina. Braz. Arch. Biol. Techn. 47:291-299.

BARTON, M.G. 1982. Intertidal vertical distribution and diets of five species of central California stichaeoid fishes. Calif. Fish. Game 68:174-182.

BENNETT, B.A. \& GRIFFITH, C.L. 1984. Factors affecting the distribution, abundance and diversity of rock-pool fishes on the Cape Peninsula, South Africa. S. Afr. J. Zool. 19:97-104.

BRIGGS, J.C. \& BOWEN, B.W. 2012. A realignment of marine biogeographic provinces with particular reference to fish distributions. J. Biogeogr. 39(1):12-30.

CARDINALE, B.J., DUFFY, J.E., GONZALEZ, A., HOOPER, D.U., PERRINGS, C., VENAIL, P., NARWANI, A., MACE, G.M., TILMAN, D., WARDLE, D.A., KINZIG, A.P., DAILY, G.C., LOREAU, M., GRACE, J.B., LARIGAUDERIE, A., SRIVASTAVA, D.S. \& NAEEM, S. 2012. Biodiversity loss and its impact on humanity. Nature 486(7401):59-67.

CASTELlANOS-GALINDO, G.A., GIRALDO, A. \& RUBIO, E.A. 2005. Community structure of an assemblage of tidepool fishes on a tropical eastern Pacific rocky shore, Colombia. J. Fish. Biol. 67:392-408.

COX, K.N. 2007. Abundance and distribution patterns of intertidal fishes at three sites within Redwood National and State Parks, 2004-05. Master dissertation, Humboldt State University, Arcata, CA.

COX, T.E., BAUMGARTNER, E., PHILIPPOFF, J. \& BOYLE, K.S. 2010. Spatial and vertical patterns in the tidepool fish assemblage on the island of Òahu. Env. Biol. Fish. 90(4):329-342.

CUNHA, F.E.A. \& ROSA, I.L. 2006. Anaesthetic effects of clove oil on seven species of tropical reef teleosts. J. Fish. Biol. 69(5):15041512.

DAVIS, J.L.D. 2000. Spatial and seasonal patterns of habitat partitioning in a guild of southern California tidepool fishes. Mar. Ecol.-Prog. Ser. 196:253-268.

EVANS, D.H., CLAIBORNE, J.B. \& KORMANIK, G.A. 1999. Osmoregulation, acid-base regulation, and nitrogen excretion. In Intertidal fishes: life in two worlds (Horn, M.H., Martin, K.L.M. \& Chotkowski, M.A., ed.). Academic Press, San DiegoCA, p.79-96. 
FLETCHER, S., SAUNDERS, J., HERBERT, R., ROBERTS, C. \& DAWSON, K. 2012. Description of the ecosystem services provided by broad-scale habitats and features of conservation importance that are likely to be protected by Marine Protected Areas in the Marine Conservation Zone Project area. Natural England Commissioned Reports, Peterborough, UK.

FROESE, R. \& PAULY, D. 2014. FishBase. World Wide Web electronic publication, www.fishbase.org, version (08/2014).

GERHARDINGER, L.C., FREITAS, M.O., ANDRADE, Á.B. \& RANGEL, C.A. 2006. Omobranchus punctatus (Teleostei: Blenniidae), an Exotic Blenny in the Southwestern Atlantic. Biol. Invasions 8(4):941-946.

GIBSON, R.N. 1972. The vertical distribution and feeding relationships of intertidal fish on the Atlantic Coast of France. J. Anim. Ecol. 41(1):189-207.

GIBSON, R.N. 1986. Intertidal teleosts: life in a fluctuating environment. In The behavior of teleosts fishes (Pitcher, T.J., ed.). Croom Helm, London, p.388-407.

GIBSON, R.N. 1999. Movement and homing in intertidal fishes. In Intertidal fishes: life in two worlds (Horn, M.H., Martin, K.L.M. \& Chotkowski, M.A., ed.). Academic Press, San DiegoCA, p.97-125.

GIBSON, R.N. \& YOSHIYAMA, R.M. 1999. Intertidal fish communities. In Intertidal fishes: life in two worlds (Horn, M.H., Martin, K.L.M. \& Chotkowski, M.A., ed.). Academic Press, San DiegoCA, p.264-296.

GRIFFITHS, S. 2000. The use of clove oil as an anaesthetic and method for sampling intertidal rockpool fishes. J. Fish. Biol. 57(6):1453-1464.

GRIFFITHS, S.P., DAVIS, A.R. \& WEST, R.J. 2006. Role of habitat complexity in structuring temperate rockpool ichthyofaunas. Mar. Ecol.-Prog. Ser. 313:227-239.

GROSSMAN, G.D. 1982. Dynamics and organization of a rocky intertidal fish assemblage: the persistence and resilience of taxocene structure. Am. Nat. 119(5):611-637.

HALPERN, B.S., WALBRIDGE, S., SELKOE, K.A., KAPPEL, C.V., MICHELI, F., D'AGROSA, C., BRUNO, J.F., CASEY, K.S., EBERT, C., FOX, H.E., FUJITA, R., HEINEMANN, D., LENIHAN, H.S., MADIN, E.M.P., PERRY, M.T., SELIG, E.R., SPALDING, M., STENECK, R. \& WATSON, R. 2008. A global map of human impact on marine ecosystems. Science. 319(5865):948-952.

HERNÁNDEZ, C.E., NEILL, P.E., PULGAR, J.M., OJEDA, F. P. \& BOZINOVIC, F. 2002. Water temperature fluctuations and territoriality in the intertidal zone: two possible explanations for the elevational distribution of body size in Graus nigra. J. Fish. Biol. 61(2):472-488.

HOLMLUND, C.M. \& HAMMER, M. 1999. Ecosystem services generated by fish populations. Ecol. Econ. 29:253-268.

HORN, M.H., MARTIN, K.L.M. \& CHOTKOWSKI, M.A. 1999. Introduction. In Intertidal fishes: life in two worlds (Horn, M.H., Martin, K.L.M. \& Chotkowski, M.A., ed.). Academic Press, San Diego, CA, p.1-6.

IRIGOYEN, A.J. \& GALVÁN, D.E. 2009. Peces de arrecifes argentinos. Proyecto Arrecife, Puerto Madryn.

KING, M. 2007. Fisheries biology, assessment, and management. 2nd. Blackwell Publishing Ltd, OxfordUK.

KRÜCK, N.C., CHARGULAF, C.A., SAINT-PAUL, U. \& TIBBETTS, I.R. 2009. Early post-settlement habitat and diet shifts and the nursery function of tidepools during Sillago spp. recruitment in Moreton Bay, Australia. Mar. Ecol.-Prog. Ser. 384:207-219.

LASSO-ALCALÁ, O., NUNES, J.L.S., LASSO, C., POSADA, J., ROBERTSON, R., PIORSKI, N.M., VAN TASSELL, J.L., GIARRIZZO, T. \& GONDOLO, G. 2011. Invasion of the IndoPacific blenny Omobranchus punctatus (Perciformes: Blenniidae) on the Atlantic Coast of Central and South America. Neotrop. Ichthyol. 9(3):571-578

LUIZ J.R., O.J., CARVALHO-FILHO, A., FERREIRA, C.E.L., FLOETER, S.R., GASPARINI, J.L. \& SAZIMA, I. 2008. The reef fish assemblage of the Laje de Santos Marine State Park,
Southwestern Atlantic: annotated checklist with comments on abundance, distribution, trophic structure, symbiotic associations, and conservation. Zootaxa. 1807:1-25.

MACIEIRA, R.M. \& JOYEUX, J.-C. 2009. Length-weight relationships for rockpool fishes in Brazil. J. Appl. Ichthyol. 25(3):358-359.

MACIEIRA, R.M. \& JOYEUX, J.-C. 2011. Distribution patterns of tidepool fishes on a tropical flat reef. Fish. B-NOAA. 109(3):305315.

MACIEIRA, R.M., SIMON, T., PIMENTEL, C.R. \& JOYEUX, J.-C. 2015. Isolation and speciation of tidepool fishes as a consequence of Quaternary sea-level fluctuations. Environmental Biology of Fishes 98, 385-393.

MAHON, R. \& MAHON, S.D. 1994. Structure and resilience of a tidepool fish assemblage at Barbados. Env. Biol. Fish. 41(1-4):171-190.

MANNINO, M.A. \& THOMAS, K.D. 2002. Depletion of a resource? The impact of prehistoric human foraging on intertidal mollusc communities and its significance for human settlement, mobility and dispersal. World Archaeol. 33(3):452-474.

MARTIN, K.L.M. \& BRIDGES, C.R. 1999. Respiration in water and air. In Intertidal fishes: life in two worlds (Horn, M.H., Martin, K.L.M. \& Chotkowski, M.A., ed.). Academic Press, San Diego, CA, p.54-78.

MEIRELES, A.J.A.D. 2011. Geodinâmica dos campos de dunas móveis de Jericoacoara / CE-BR. Mercator. 10(22):169-190.

MENEZES, N.A. \& FIGUEIREDO, J.L.D. 1985. Manual de peixes marinhos do sudeste do Brasil - Volume V (Teleostei 4). Museu de Zoologia, Universidade de São Paulo, São Paulo.

MMA 2011. Resumo executivo: Plano de manejo do Parque Nacional de Jericoacoara. Instituto Chico Mendes de Conservação da Biodiversidade - ICMBio, Brasília.

MOBERG, F. \& RÖNNBÄCK, P. 2003. Ecosystem services of the tropical seascape: interactions, substitutions and restoration. Ocean Coast. Manage. 46:27-46.

MOBLEY, C.M. \& MCCALLUM, W.M. 2001. Prehistoric intertidal fish traps from central southeast Alaska. Can. J. Acha. 25:28-52.

MOUILLOT, D., DUMAY, O. \& TOMASINI, J.A. 2007. Limiting similarity, niche filtering and functional diversity in coastal lagoon fish communities. Estuar. Coast. Shelf. S. 71(3-4):443-456.

NELSON, J.S. 2006. Fishes of the World. 4th. John Wiley \& Sons, Inc, Hoboken, NJ.

NORTON, S.F. \& COOK, A.E. 1999. Predation by fishes in the intertidal In Intertidal fishes: life in two worlds (Horn, M.H., Martin, K.L.M. \& Chotkowski, M.A., ed.). Academic Press, San Diego, CA, p.223-263.

NUNES, J.L.S., PASCOAL, N.G.D.A. \& PIORSKI, N.M. 2011. Peixes intertidais do Maranhão. In Peixes marinhos e estuarinos do Maranhão (Nunes, J.L.S. \& Piorski, N.M., ed.). Café \& Lápis, São Luís, MA, p.105-139.

PIMENTEL, D. 2011. Introduction: nonnative species in the world. In Biological invasions: economic and environmental costs of alien plant, animal, and microbe species (Pimentel, D., ed.). CRC Press, Boca Raton, FL, p.1-7.

PROCHAZKA, K., CHOTKOWSKI, M.A. \& BUTH, D.G. 1999. Biogeography of rocky intertidal fishes. In Intertidal fishes: life in two worlds (Horn, M.H., Martin, K.L.M. \& Chotkowski, M.A., ed.). Academic Press, San Diego, CA, p.332-355.

RANGEL, C.A. \& GUIMARÃES, R.Z.P. 2010. Taxonomia e distribuição da família Blenniidae (Teleostei: Blennioidei) na costa leste do Brasil. Zoociências. 12(1):17-41.

ROJAS, J.M. \& OJEDA, F.P. 2010. Spatial distribution of intertidal fishes: a pattern dependent on body size and predation risk? Env. Biol. Fish. 87(3):175-185.

ROSA, R.S., ROSA, I.L. \& ROCHA, L.A. 1997. Diversidade da ictiofauna de poças de maré da praia do Cabo Branco, João Pessoa, Paraíba, Brasil. Rev. Bras. Zoo. 14:201-212.

SPRINGER, V.G. \& GOMON, M.F. 1975. Revision of the blenniid fish genus Omobranchus: with descriptions of three new species and notes on other species of the tribe Omobranchini. Smithsonian Institution Press, Washington, DC. 
Machado, F.S. et al.

STEELE, T.E. \& KLEIN, R.G. 2008. Intertidal shellfish use during the Middle and Later Stone Age of South Africa. Archaeofauna. 17:6376.

THOMPSON, R.C., CROWE, T.P. \& HAWKINS, S.J. 2002. Rocky intertidal communities: past environmental changes, present status and predictions for the next 25 years. Environ. Conserv. 29(2):168-191.
WESTNEAT, M.W. \& ALFARO, M.E. 2005. Phylogenetic relationships and evolutionary history of the reef fish family Labridae. Mol. Phylogenet. Evol. 36(2):370-390.

WILDING, T.A., PALMER, E.J.L. \& POLUNIN, N.V.C. 2010. Comparison of three methods for quantifying topographic complexity on rocky shores. Mar. Environ. Res. 69(3):143-151.

Received 30/10/2014 Revised 30/10/2014 Accepted 4/02/2015 


\section{Appendix}

Museum vouchers of specimens from the Jericoacoara National Park, deposited in the ichthyological collection of the Grupo de Ecologia Aquática (GEA.ICT). Species arranged in alphabetical order. Abudefduf saxatilis GEA.ICT\#01694; Acanthurus chirurgus GEA.ICT\#00071; Ahlia egmontis GEA.ICT\#00019; Bathygobius geminatus GEA.ICT\#00325; Bathygobius soporator GEA.ICT\#00382; Gobiesox barbatulus GEA.ICT\#00166; Gymnothorax funebris GEA.ICT\#00293; Haemulon parra GEA.ICT\#00293; Hypleurochilus fissicornis GEA.ICT\#01693; Labrisomus nuchipinnis GEA.ICT\#00410; Lutjanus jocu: GEA.ICT\#00186; Malacoctenus delalandei GEA.ICT\#00158; Mugil curema GEA.ICT\#01692; Omobranchus punctatus GEA.ICT\#01691; Scartella cristata GEA.ICT\#00253; Sparisoma frondosum GEA.ICT\#01690. 